\title{
sciendo
}

This journal provides immediate open access to its content under the Creative Commons BY 4.0 license. Authors who publish with this journal retain all copyrights and agree to the terms of the above-mentioned CC BY 4.0 license.

DOI: $10.2478 /$ seeur-2020-0009

\section{TEACHERS' EXPERIENCES WITH ONLINE TEACHING USING THE ZOOM PLATFORM WITH EFL TEACHERS IN HIGH SCHOOLS IN KUMANOVA}

\author{
PhD. Cand., Adelina Ramadani,
}

Faculty of Language, Cultures and Communication, South East European University, North Macedonia ar18115@seeu.edu.mk

Prof. Dr. Brikena Xhaferi,

Faculty of Language, Cultures and Communication, South East European University, North Macedonia

b.xhaferi@seeu.edu.mk

\begin{abstract}
The Covid-19 virus appeared very fast around the globe and caused many damages to all of us. It caused many troubles in different fields such as: economics, business, factories, education etc. Many institutions around the world faced challenges and tried to find solutions. But the most difficult challenge was about online teaching; most of the countries suggested many strategies and methods to teach students and learners through distinctive materials and online platforms. It was suggested to use online programs as Google Classroom, Google Meet, Skype, Zoom and many other technological tools in order to help learners to continue with their studies. Using online platform in our country was very demanding because of many factors that influenced all of us. Although many teachers from different schools used many devices during the pandemic, ZOOM was the main one. Teachers had different experiences and challenges during their teaching process through online platforms. They had many problems especially in the assessment and evaluation part; it was very difficult to evaluate learners through technology
\end{abstract}


instruments and grading them correctly. This study is about teachers' experience with the ZOOM platform, to discover if teachers had difficulties with online teaching during the pandemic. This case study's outcomes present valuable information to the teachers and future researches because there is a limited number of studies in this field.

Keywords: online teaching, teachers, learners, ZOOM

\section{INTRODUCTION}

The teaching process in this pandemic situation was affected in all ways and became one of the most important factors to consider organizing educational system as transferring from classic learning to online learning. This process of transfer does not happen fast because there are many factors that impact and cause many problems. "Moving smoothly from an environment of conventional education to distance and virtual learning could not happen overnight. This rapid transformation is linked to various obstacles and challenges at this point" (Crawford, Butler-Henderson, Rudolph, \& Glowatz, 2020 as cited in Anwar \& Adnan, 2020 p.46). Transferring the teaching process to online learning is very difficult because there are many obstacles that teachers face and try to find the appropriate strategies to teach learners through online teaching. "However, there is ambiguity and disagreement about what to teach, how to teach, the workload of teachers and students, the teaching environment, and the implications for education equity" (Zhang, Wang, Yang, \& Wang, 2020) (as cited in Ali, 2020 p.16). Based on the citation, there are many agreements and disagreements about online teaching between teachers, students and educational institutions. In order to develop an online course successfully, some decisions are made in the implementation process. Sun and Chen (2006), state that "effective online instruction is dependent upon 1) well-designed course content, motivated interaction between the instructor and learners, well-prepared and fullysupported instructors; 2) creation of a sense of online learning community ; and 3) rapid advancement of technology" (as cited in Allo, 2020 p.3). Having online teaching with students is very hard because teachers need to organize and create online learning class in the best way possible. "Several techniques were used to deliver the distance program for a period of time" (Cohen \& Ellis, 2001) (as cited in Shadat, Sayem, Taylor, \& Mcclanachan, 2017 p.2). Teachers used many strategies and techniques to teach their 
students through online teaching and noticed advantages and disadvantages of online teaching process.

Therefore, the aim of this study is to discover the challenges that teachers face during online teaching, what kind of learning strategies teachers use to teach learners, and how EFL teachers assess and evaluate students during online teaching. This study is important because it will show the difficulties and benefits of using the ZOOM platform with students in online teaching.

\section{LITERATURE REVIEW}

The term online learning is used internationally but it has different meanings. Many authors describe this term in different ways by giving descriptions and opinions based on the research field or experience. "Online learning-Education in which instruction and content are delivered primarily over the Internet" (Watson \& Kalmon, 2005) (as cited in The Online Definition Project, 2011, p.7). Online learning is the way that instructions, content and material are delivered through internet fast and easy. Abernathy (2019) (as cited in Tamm, 2019 p.1), states that "E-learning, also referred to as online learning or electronic learning, is the acquisition of knowledge which takes place through electronic technologies and media. In simple language, e-learning is defined as "learning that is enabled electronically". What is more, Bates (2016, p.2) claims that, "Online learning is a form of distance education in which a course or program is intentionally designed in advance to be delivered fully online". Online learning is distance learning which gives learners the opportunity to learn without their presence in the classroom. According to The Economic Times (2020), “A learning system based on formalised teaching but with the help of electronic resources is known as E-learning. While teaching can be based in or out of the classrooms, the use of computers and the Internet forms the major component of E-learning". In addition, online learning can be described as "learning that takes place partially or entirely over the Internet" (U.S. Department of Education, 2010) (as cited in Gilbert, 2015 p.3). "Online learning is a form of distance learning or distance education, which has long been a part of the American education system, and it has become the largest sector of distance learning in recent years" (Bartley \& Golek, 2004; Evans \& Haase, 2001) (as cited in Nguyen, 2015 p.309). Similarly Oblinger and Hawkins (2005) 
noted that "e-Learning has transformed from a fully-online course to using technology to deliver part or all of a course independent of permanent time and place". Also the European Commission (2001) describes, "e-Learning as the use of new multimedia technologies and the Internet to increase learning quality by easing access to facilities and services as well as distant exchanges and collaboration" (as cited in Arkorful, 2014 p.398).

\section{THE ROLE OF THE ZOOM PLATFORM IN ONLINE TEACHING}

Online teaching plays a significant role in education nowadays because of Covid-19 and most of the countries applied different tools of technology in education. One of them is ZOOM, a tool that helps teachers and learners to work together. But first we should know what this platform is, how it works, and what kind of benefits it has in education. "Zoom combines video conferencing, online meetings and in-conference group chat info one easy-to-use tool that is ideal for online class use, and group work" (Learning Technology Center, 2018 p.1). The ZOOM platform is a tool that makes the teaching process easier and gives the opportunity to teachers and learners to expand their knowledge better. Many institutions in different countries used ZOOM in order to increase student's motivation and interest about the English language. "Many universities are training students to integrate technology like ZOOM applications to be used during instruction within education because people are rapidly adapting to accessing these technologies to facilitate communication which leads to the widespread popularity of distance learning" (Romoszowski \& Mason, 2004). "This comes as a solution for educational researchers who are constantly trying to develop innovative means to enhance the interactivity of the learning process in order to stimulate students' motivation and engagement in discussions for knowledge exchange, which also lead to developing general language learning" (Tanti, 2012) (as cited in Ayoub, 2019 p.4). ZOOM is a very useful platform and effective for both teachers and learners because learners work together and improve the language skills appropriately. They are more motivated and eager to learn the target language through technology, in this case the ZOOM platform. Comparing ZOOM with other tools such as Viber or WhatsApp, teachers had more difficulties during online teaching because these tools did not offer the opportunities for teaching as ZOOM platform did. Teachers had more challenges in using these tools because they could not teach learners properly 
until they began using ZOOM. On the other hand, there are disadvantages of using ZOOM because teachers have difficulties to assess and evaluate learners in an appropriate manner. Some of the learners are not interested in working with ZOOM or using technology in general because they are shy, and they are not able to perform their knowledge through online teaching and learning.

\section{RESEARCH METHODOLOGY}

This research is proposed to be carried out by using a qualitative approach in order to analyze and get better results of teachers' experiences with the ZOOM platform. Primary data is collected to be analyzed very carefully. The main research instrument used was the interview conducted with EFL teachers at high schools in Kumanova. The number of participants was 6 teachers between the age of 32-47, including four males and two females. The teachers' experiences vary because most of the teachers did not have IT skills to use different technological tools and they faced many challenges during online teaching, but they all used ZOOM during COVID-19 pandemic in the previous school year.

\section{RESEARCH QUESTIONS}

During this research, the following questions are addressed:

- Which are the challenges that teachers face during online teaching?

- What kind of strategies teachers use to teach learners through ZOOM platform?

- How do EFL teachers assess and evaluate students in online teaching?

- Has the ZOOM platform increased students' motivation about the target language?

\section{RESEARCH INSTRUMENT}

The Interview (See appendix 1) was composed based on the researchers' experiences with online teaching and it contained 10 questions. All questions are related to teachers' experiences with online teaching via ZOOM. 


\section{INTERVIEW QUESTIONS}

1. In what aspects do you think online learning design and delivery is different than face-to-face teaching and learning?

2. What do you think makes online teaching and learning successful?

3. What activities would you suggest for online teaching?

4. What teaching materials have you used for online teaching using ZOOM?

5. How did you assess students' participation in ZOOM?

6. What are some effective ways of monitoring students' engagement and learning during online courses?

7. How was the student motivation in online classes?

8. Was there enough online discussion with the students?

9. Do you believe that ZOOM is a very good platform for online teaching? Why or why not?

10. How did you motivate shy students to engage in ZOOM?

\section{RESULTS}

In the research instrument, 6 teachers participated in the interview. Each teacher expressed their opinions about online teaching especially using ZOOM based on their experience. Different opinions will be illustrated below on using the ZOOM platform in their online teaching.

\section{Question 1: In what aspects do you think online learning design and delivery is different than face-to-face teaching and learning?}

Four teachers think that online learning will never fully replace face-to-face or classroom learning. In comparison to face to face learning where the number of students is limited, online learning allows you to share your teaching class with as many students you need. If teachers do a combination of both online and face-to-face teaching methodologies, it is the best combination ever done! Online learning design and delivery is different than face-to-face teaching and learning because in teachers' opinion face-to-face has many benefits for the person in front of us. First of all body language means a lot when learning a new notion, and in that way students tend to concentrate more and also remember more. The teachers' voice frequency, mimics and gestures are something that students remember for the rest of their lives. But some of them explained that computers can facilitate step-by-step learning; computer technology is advancing very fast and in the 
aspect of learning it is more attractive than traditional one. The computer network enables students from different countries to learn and jointly solve certain learning problems. Online learning has its benefits as students can learn from the comfort of their home. As teachers, they prefer when their students to be in front of them, so they give them immediate answers; teachers remember their students' faces and their capacity of learning.

\section{Question 2: What do you think makes online teaching and learning successful?}

Teacher's feedback about this question is very interesting as each of them have different opinions about online teaching. Five teachers stated that online learning creates access to lots of resources for teachers and students of all over the world. By using a good and useful platform of online learning, it provides or delivers a very rich learning pathway. Teachers think it is already accepted, that technology is in itself a bridge to learning, more than a kind of destination, and that the main factor for the introduction of new tools in learning, such as online, is the involvement of an excellent teacher. While two of them say that online teaching and learning becomes successful when students accomplish their requirements successfully. When students show good learning abilities and give positive results that is when learning becomes successful. Given tasks, homework, quizzes, tests, all these are proof of students' work and commitment to a subject. When online, students can get more data in the moment and be prepared, but they can also use Internet as a cheating method which is something negative. Or, for e.g. having another person behind the camera, while having an exam, they have experienced this kind of cheating, and the student got the highest mark.

\section{Question 3: What activities would you suggest for online teaching?}

According to the six teachers, online teaching can be provided by a lot of platforms or other resources such as: ZOOM, Google Classroom, slide share, video maker platform, etc. They also claim that the best activity for online teaching is discussion about the topic including questions from students about unclear notions. Nevertheless, ZOOM was the most useful tool which helped the teaching and learning process to progress throughout COVID-19. 


\section{Question 4: What teaching materials have you used for online teaching using ZOOM?}

Six teachers claim that that they have worked according to their lesson plans, which include particular English books, workbooks from which they have provided the lesson, textbooks in PDF and video tutorials. However, they could use other illustrative elements if they wanted to make their lesson more attractive.

\section{Question 5: How did you assess students' participation in ZOOM?}

Four teachers assessed students by observations and evaluation with school students for tasks and activities, such as control and reflection on completed tasks, discussions, presentations, etc. Two of the teachers assessed their students by asking for students' recordings and sent a voice recording to them, sometimes they sent pictures of their work, and this way teachers assessed them and their work.

\section{Question 6: What are some effective ways of monitoring students' engagement and learning during online courses?}

According to the six teachers, monitoring student engagement is easier during online classes than traditional ones, because they afford teachers the comfort of being able to teach in their own living room, while also at the same time using different learning elements such as: PowerPoint slide sharing, video sharing, chatting). Teachers never felt tired after their ZOOM classes but exited.

\section{Question 7: How was the student motivation in online classes?}

Three teachers state that surprisingly students have been highly motivated (maybe the reason is that they like changes during teaching and learning process). What surprised them the most was the interest of some students who were not excellent ones, and all the time posed questions and were encouraged into the lesson process! While three of the teachers claim that sometimes students felt demotivated because if someone had excellent grades, he/she went to the library, but now he/she could not do that, or the family is too big and students do not have the appropriate place to learn and the other teachers say that they were not motivated enough in online classes. 


\section{Question 8: Was there enough online discussion with the students?}

Six teachers claim that sometimes Zoom lessons could have technological difficulties. This fact is not anyone's fault because it is a technological issue. For ZOOM to be effective, you really need a stable Wi-Fi. Without that, the sound is not stable; students and teachers will hear an echo and repeat themselves. Regarding teachers' schedule, the class duration was 20 minutes maximum, so teachers think there was not enough discussion about topics, just going straight forward to aims. Therefore, according to these kinds of problems teachers could not say that the discussions were effective enough!

\section{Question 9: Do you believe that ZOOM is a very good platform for online teaching?} Why or why not?

Six teachers state that ZOOM is the best tool that can be used in the teaching/learning process. It is also very easy to get it installed on the computer, and students simply click on the link to join their online class at a particular time, and teachers do not have to pay because it is free. ZOOM is practical for all students who continue to take lectures virtually and above all it is easily usable. Just download it and register through the required data. You can schedule appointments at certain times, and it allows teachers to talk in groups no matter how many teachers are present. Another important factor for $\mathrm{ZOOM}$ is that is compatible on all computer systems, and it is easy to use for both students and teachers.

\section{Question 10: How did you motivate shy students to engage in ZOOM?}

Six teachers state that during their experience, they have faced lots of shy students who escape from conversations or from the given duties. They have discovered that the best solution for this is to do more group games (using games that they like the most) and try to make these shy students group leaders. Also a good method to motivate them get encouraged is to praise them all the time by saying that they are doing very well even if they not actually. According to these points, teachers have noticed an improvement of these students. 


\section{CONCLUSION}

Important conclusions can be brought from the data obtained by the instruments of this research. The following conclusions are a confirmation of the important issues in teaching and learning online with the ZOOM platform and different teachers' experiences which should be taken into consideration by future researches. Based on the interview results, it can be concluded that: four teachers think that online learning can never replace the traditional learning and face-to-face learning is more effective. Based on the research, using different methods and tools makes online teaching more successful because learners are prepared and they gain data rapidly. However, two teachers replied that online teaching is not always successful because there are cases when learners have the opportunity to cheat and get an excellent grade during the evaluation. Or, there are parents behind cameras that they do all the work instead of the child. Moreover, teachers claim that monitoring students' engagement is easier in online learning because teachers have the chance to teach learners in their own way using different tools such as slides, video platforms, and many other tools. According to teachers, the most important idea was to motivate shy students in order to engage in ZOOM by praising them and using interesting activities.

\section{RECOMMENDATIONS}

The study recommended that the school management should take into consideration the number of teachers sitting in the same office. Intensive training is needed in order to implement ZOOM appropriately. School management should be aware of lack of computers and laptops at schools and providing teachers with technological tools during the pandemic. Teachers' and students' motivation are closely related therefore, both groups should try very hard to work together in order to be successful. It was notable that teachers participated and responded to the instrument with the fullest transparency. The instruments helped in gaining reliable and truthful results.

\section{LIMITATIONS}

This study had several limitations because it does not include many schools of the region so we could compare the results. Also, teachers were not as cooperative as expected and 
some of them avoided participation. We have not, for example, systematically examined differences in content offered using the ZOOM platform and comparison of its features with other platforms. Finally, continuous observations and interviews with students and the interaction could have been investigated for more interesting results. 


\section{REFERENCES}

- Anwar. K \& Adnan. M (2020). Online Learning Amid the COVID-19 Pandemic: Students Perspectives. Retrieved 18 September, 2020 from: https://www.researchgate.net/publication/342371575_Online_learning_amid_the_COVI D-19_pandemic_Students_perspectives

- Ali. W (2020). Online and Remote Learning in Higher Education Institute: A Necessity in Light of Covid-19 Pandemic. ISSN 1925-4741 E-ISSN 1925-475X

- Allo. M (2020). Is the Online Learning Good in the Midst of Covid-19 Pandemic? The Case of EFL Learners. Retrieved 19 September, 2020 from:

https://www.researchgate.net/publication/340815846_Is_the_online_learning_good_in_ the_midst_of_Covid-19_Pandemic_The_case_of_EFL_learners

- Arkorful. V (2014). The Role of E-Learning, the Advantages and Disadvantages of its Adoption IN Higher Education. Retrieved 19 September, 2020 from: https://www.ijern.com/journal/2014/December-2014/34.pdf

- Ayoub. J (2019). Effective Use of Zoom Sessions (a Synchronous Learning Strategy) to Foster Success and Motivation of Lebanese University Students in Bekaa: A Case Study. Retrieved 25 September, 2020 from: https://www.awraqthaqafya.com/601/

- Bates. T (2016). Online Learning for Beginners: 1. What is Online Learning? Retrieved 21 September, 2020 from: https://www.tonybates.ca/2016/07/15/online-learning-for-beginners-1-what-is-onlinelearning/

- Gilbert. B (2015). Online Learning Revealing the Benefits and Challenges. Retrieved 22 September, 2020 from:

https://fisherpub.sjfc.edu/cgi/viewcontent.cgi?article=1304\&context=education_ETD_ masters

- International Association for K-12 Online Learning (2011). The Online Learning Definitions Project. Retrieved 20 September, 2020 from: https://aurora-institute.org/wp-content/uploads/iNACOL_DefinitionsProject.pdf

- Learning Technology Center (2018). What is Zoom? Retrieved 24 September, 2020 from:

https://clarion.edu/about-clarion/computing-services/learning-technology-center/zoomvideo-conferencing/PDFs/getting-started-with-zoom-basic.docx.pdf

- Nguyen. T (2015). The Effectiveness of Online Learning: Beyond No Significant Difference and Future Horizons. Retrieved 23 September, 2020 from: https://jolt.merlot.org/Vol11no2/Nguyen_0615.pdf

- Shadat. M, Sayem. M, Taylor. B \& Mcclanachan. M (2017). Effective Use of Zoom Technology and Instructional Videos to Improve Engagement and Success of Distance Students in Engineering. Retrieved 19 Septemeber, 2020 from: https://www.researchgate.net/publication/323268816_Effective_use_of_Zoom_technolo gy_and_instructional_videos_to_improve_engagement_and_success_of_distance_stude nts_in_Engineering 
- Tamm. S (2019). What is E-Learning? Retrieved 20 September, 2020 from: https://e-student.org/what-is-e-learning/

- The Economic Times (2020). Definition of 'E-Learning'. Retrieved 21 September, 2020 from:

https://economictimes.indiatimes.com/definition/e-learning 


\section{APPENDIX}

\section{Interview questions}

1. In what aspects do you think online learning design and delivery is different than face-to-face teaching and learning?

2. What do you think makes online teaching and learning successful?

3. What activities would you suggest for online teaching?

4. What teaching materials have you used for online teaching using ZOOM?

5. How did you assess students' participation in ZOOM?

6. What are some effective ways of monitoring students' engagement and learning during online courses?

7. How was the student motivation in online classes?

8. Was there enough online discussion with the students?

9. Do you believe that ZOOM is a very good platform for online teaching? Why or why not?

10. How did you motivate shy students to engage in ZOOM?

11. Adapted from: Rapanta. C, Botturi. D, Goodyear. P, Guardia. L \& Koole. M (2020). Retrieved from: https://link.springer.com/article/10.1007/s42438-02000155-y 